at the scope of the book, and declared, "the conception is as scientific as the exposition is lucid."

I mention these, for I recognise that in academic circles here it is the custom to " drink the label," but I give no value to mere authority; I attach the utmost importance, however, to the serried march of my own arguments proceeding from the deepest ascertainable base in regular succession to the conclusions offered.

Would any one guess from the statements of the reviewer that this presentation of psychology, so far from depending on $\mathrm{my}$ personal feelings, is entirely objective in conception, and that I do not ask the reader to take my series of "Fundamental Processes" at my word, but offer the demonstration of their "necessity and sufficiency " in an exposition of which the meticulous and exhaustive character may be excused only by the paramount desire for rigour?

The reviewer is wrong even when he attempts to soften a disparaging note: "The choice of the name [Alétheian system] seems to imply a slight on other systems, but probably nothing of the kind is intended." What I intend to imply is that this work stands to other systems in a relation corresponding to that of Pasteur to the writings of the physicians of Louis XIV., or that of Galileo to the Schoolmen who discussed phenomena by talking of "proper" and "improper" motion, and decided questions not by illuminating from the foundation but simply by appealing to academic shibboleths.

That, too, is the meaning of resting my hope, not on " the young" as your critic cautelously insinuates, but on uncontaminated and capable young minds.

ARTHUR LYNCH.

8o Antrim Mansions, Haverstock Hill, N.W. October 30.

Col. LyNCH's complaint of ill-usage to his book in the review in NATURE amounts to a charge that the reviewer has failed to appreciate the originality and the scientific importance of the author's system of psychology. This charge is true. All I can do is to assure your readers that I wrote without consciousness of prejudice, and only after a thoughtful reading of the book and sincere attempt to discover the author's meaning. I respect the author and had no intention of giving offence.

I am surprised and sorry that my reference to the author's former book is resented. May I say that the playful, not spiteful, allusion to the reception of the greatest philosophical book of the greatest British philosopher, Hume's "Treatise of Human Nature," was not meant to bear any reference to financial matters. Col. Lynch says that the whole edition of his former book has, in fact, been sold. I am glad, but I had no thought about it. Possibly Col. Lynch does not know that the whole edition of Hume's book was sold and that he was not smarting under financial loss when he said that it had "fallen still-born from the press."

THE Reviewer.

\section{Psycho-Analysis and Anthropology.}

Dr. Malinowski's illuminating letter in NATURE of November 3 contains a reference to what he rightly calls my "harsh judgment" upon Freud's incursion into ethnology. But he has not made it clear that I was criticising the views expressed in "Totem and Taboo" and not Freud's teaching as a whole. For $\mathrm{I}$ am in complete agreement with the latter part of Dr. Malinowski's letter, in which he insists upon the value of Freud's reform in psychological method for the solution of anthropological problems.

$$
\text { NO. } 2821 \text {, VOL. } 1 \text { I } 2 \text { ] }
$$

The examples quoted by Dr. Malinowski himself illustrate the aspect of Freud's work which is not merely fallacious but also in conflict with the essential part of his own teaching. Moreover, Freud entered the ethnological arena without preparing himself for the fray by making himself acquainted with the facts he attempts to explain. No one with any knowledge of the practices of totemism, exogamy, and taboo, ran fail to recognise that Freud is unacquainted with the essential facts and associations of these remarkable customs, and that his suggestions as to their origin are irrelevant and nonsensical.

The essence of Freud's reform in psychological method was his insistence upon the fact that all the vagaries of behaviour and belief, the phantasies of the sleeping and waking life, had definite causes, which could be discovered and traced back to their real source in the individual experience of each of his subjects. But after exploiting this method of analysis of individual experience up to a certain point, Freud suddenly changes his tactics and quite inconsequently postulates a " universal symbolism," into conformity with which he tries to force the in cidents of each individual's distinctive experience. This appears to me to be in direct conflict with the essential feature of his theory and practice. Moreover, this speculation of " universal symbolism" is responsible for most of the unsavouriness of Freud's methods which have excited such violent antagonism, and I believe not without some measure of justification. It is the duty of those who appreciate the value of the really fundamental part of Freud's reform to expose the inconsistency of these accretions which imperil the whole doctrine.

The criticism of his adventure into ethnology is inspired not only by the realisation of his lack of knowledge of the subject, but also by the fact that it is the more than doubtful and inconsistent part of his psychological teaching which he proposes to use as a panacea for the cure of ethnological difficulties. At a time when the ethnological doctrine of " psychic unity " is at its last gasp, Freud comes along with the fantastic nostrum of "typical symbols" and tries to revive it.

In the Monist of last January, I have analysed the claims made by Freud in "Totem and Taboo," and exposed their futility. But as even the qualified support Dr. Malinowski accords to this aspect of psycho-analytic method involves a very grave danger to anthropology, I have repeated here some of the arguments set forth in greater detail in that criticism.

G. Elliot Smith.

The Origin of Petroleum.

I HAVE read, with much interest, the article on the "Origin of Petroleum" in NATURE of October 27 , p. 627 .

In a discussion of this nature one of the great difficulties, as mentioned by Mr. Cunningham-Craig, is for geologists and chemists to meet on common ground. This applies, for example, to a point raised in the article in NATURE as well as during the discussion at the Institution of Petroleum Technologists, in the words to "formulate any one hypothesis to explain the formation of such complex mixtures as mineral oils, and still more difficult to account for the great diversity in chemical composition exhibited by mineral oils from different localities." Considering coals as analogous, are not the chemical and physical variations between lignite and anthracite fully as great as those found throughout the range of petroleums? Yet no one casts doubt on the vegetable origin of coal on the score of the almost infinite variety of coal. 